\title{
The impact of firm and industry characteristics on small firms' capital structure
}

\author{
Hans Degryse $\cdot$ Peter de Goeij $\cdot$ Peter Kappert
}

Accepted: 1 March 2010/Published online: 3 April 2010

(C) The Author(s) 2010. This article is published with open access at Springerlink.com

\begin{abstract}
We study the impact of firm and industry characteristics on small firms' capital structure, employing a proprietary database containing financial statements of Dutch small and medium-sized enterprises (SMEs) from 2003 to 2005. The firm characteristics suggest that the capital structure decision is consistent with the pecking-order theory: Dutch SMEs use profits to reduce their debt level, and growing firms increase their debt position since they need more funds. We further document that profits reduce in particular short-term debt, whereas growth increases long-term debt. We also find that inter- and intraindustry effects are important in explaining small firms' capital structure. Industries exhibit different average debt levels, which is in line with the trade-off theory. Furthermore, there is substantial intra-industry heterogeneity, showing that the degree of industry
\end{abstract}

Hans Degryse is affiliated with CentER, EBC, is a CESIfo research fellow and holds the TILEC-AFM Chair on Financial Market Regulation. Peter de Goeij is affiliated with CentER and is a senior researcher for the TILEC-AFM research network on Financial Market Regulation.

H. Degryse · P. de Goeij ( $\square)$

Department of Finance, Tilburg University, Warandelaan

2, 5037AB Tilburg, The Netherlands

e-mail: p.c.degoeij@tilburguniversity.nl

P. Kappert

Corporate Clients Nederland, Rabobank International, P.O. Box 294, 6800 AG Arnhem, The Netherlands competition, the degree of agency conflicts, and the heterogeneity in employed technology are also important drivers of capital structure.

Keywords Capital structure $\cdot$ Panel data . Pecking-order theory - Trade-off theory - SME . Industry effects

JEL Classifications $\quad \mathrm{C} 23 \cdot \mathrm{G} 32 \cdot \mathrm{G} 30 \cdot \mathrm{L} 26$

\section{Introduction}

The capital structure choice is one of the most important decisions faced by firm management. While many studies tackle the capital structure decision, most empirical work deals with large publicly listed firms which often have several types of securities traded (see Frank and Goyal 2008 for a recent review). Small unlisted firms, however, make up for more than $90 \%$ of all existing firms, and are the engine of growth in most economies. In this paper we study firm and industry characteristics that determine the capital structure of small unlisted firms in The Netherlands. The capital structure decision of small firms comes closest to the standard textbook case which considers the choice between debt and equity. Indeed, small Dutch firms typically only decide from which banks to borrow and do not face other complicating issues such as the choice between private and public debt, or which type of securities to 
issue. While previous studies on industry effects focus on larger firms, studying industry characteristics for small firms is particularly important as small firms are more likely to be single-line businesses.

We exploit a large and detailed proprietary database with financial statements of Dutch SMEs from 2003 to 2005 . The advantage of this proprietary dataset over publicly available datasets is that it contains detailed information on many small firms. Indeed, firms often only report partial information to public datasets, whereas they are requested to provide more details to their financiers. Another unique feature of the database is its sheer size. In our analysis, we use an unbalanced panel that contains about 100,000 firm-year observations, covering eight different industries over 3 years. The dataset contains many very small firms, which distinguishes this study further from earlier SME capital structure studies that have medium-sized firms in their data (Michaelas et al. 1999; Sogorb-Mira 2005). SME capital structure has been investigated before for other European countries, for example the UK (Michaelas et al. 1999), Spain (Sogorb-Mira 2005), and Belgium (Heyman et al. 2008). Dutch SMEs have been considered together with a number of other European countries in a study of Hall et al. (2004).

The Dutch case is particularly interesting, because compared with the USA or the UK, financial markets are much less accessible for small businesses. Banks are the major financiers for SMEs, and the banking sector in The Netherlands is among the most concentrated in the world (see, e.g., Cetorelli and Gambera 2001). Our dataset enables us to investigate whether the empirical results in The Netherlands are different from the results in other countries and from those of large firms. An additional interesting feature of our dataset is that we can test the impact of both firm and industry characteristics on SME capital structure (see also Michaelas et al. 1999). This allows us to investigate the importance of the pecking-order theory and trade-off theory both in general and for individual industries. Previous studies such as Balakrishnan and Fox (1993), Bradley et al. (1984), and MacKay and Phillips (2005) have found various impacts of inter- and intra-industry effects for large publicly listed firms. In line with Michaelas et al. (1999), we study inter-industry effects of capital structure for unlisted SMEs, but link them more closely to the importance of the pecking-order theory and trade-off theory. Furthermore, we investigate intra-industry heterogeneity in capital structure.

Our findings can be summarized as follows. First, the firm characteristics show that the capital structure decision for Dutch SMEs is consistent with the predictions of the pecking-order theory. This is in line with previous findings for, for example, the Spanish market (see Sogorb-Mira 2005). SMEs use profits to reduce their debt level, since they prefer internal funds over external funds. However, if a firm is growing, it increases its debt position, since it needs more funds. Furthermore, we document that profits affect in particular short-term debt, whereas growth affects long-term debt. This implies that, when internal funds are depleted, long-term debt is next in the pecking order. We also document that shortterm debt is more expensive and can be amortized easily.

Second, we find that SMEs with collateral more easily attract external finance. Moreover, we document that intangible assets and net debtors, which are often considered poor collateral, have a positive effect on the long-term debt level, suggesting that banks are able to employ these assets in their loangranting decisions. In addition, Dutch SMEs have a relatively large amount of long-term debt which is more risky for lenders.

Third, we find that long-term assets are financed with long-term debt, which is consistent with the maturity-matching principle (see, e.g., Mitchel 1991). In addition, larger firms have relatively more longterm debt, while the impact of firm size on short-term debt is insignificant. These results are in contrast with, for example, Van der Wijst and Thurik (1993), who report that, if total debt is taken into account, most firm characteristics have insignificant effects, since the effects of long-term debt and short-term debt cancel out.

Finally, we document that SME capital structure exhibits both significant inter- and intra-industry variation. The inter-industry variation is in line with the trade-off theory, which suggests that industries may have different target capital structures. We further compare the role of firm characteristics across different industries and find support for the peckingorder theory for almost all industries. The only exception is the catering and leisure sector, where more profitable firms have larger debt, suggesting that the trade-off theory dominates for this sector. We 
further find substantial intra-industry variation, as the firm fixed effects within an industry explain a substantial fraction of the variation in capital structure.

The remainder of this paper is organized as follows. In Sect. 2, we review the literature and formulate hypotheses. Section 3 presents the data as well as the econometric model. We discuss the empirical results in Sect. 4. Finally, Sect. 5 concludes.

\section{Literature review and empirical propositions}

\subsection{Theory}

Modigliani and Miller (1958) argue that capital structure is irrelevant for firm value. In the vast stream of literature following Modigliani and Miller, the irrelevance proposition has been rejected, but a conclusive answer on what factors drive capital structure has not yet been provided. Several theories explain capital structure (for a review see, e.g., Frank and Goyal 2008). The first theory is the pecking-order theory (POT) (Myers and Majluf 1984; Myers 1977, 1984), which builds upon asymmetric information between managers and investors. Firms prefer funding sources with the lowest degree of asymmetric information, since borrowing costs increase when obtaining funds from outside lenders who do not have complete borrower information. The POT implies that firms opt first for internally generated funds (a form of inside equity), then for debt, and only as a last resort, for outside equity. This theory also states that there is no optimal debt-to-equity ratio.

The second theory is the trade-off theory (TOT), which argues that a firm chooses the optimal capital structure by balancing the tax benefits of debt and the costs of financial distress (see, e.g., Brennan and Schwartz 1978; DeAngelo and Masulis 1980; Bradley et al. 1984). These costs increase with the degree of leverage. Finally, the market timing theory of Baker and Wurgler (2002) states that management raises equity in hot equity markets but issues debt in cold equity markets. However, for our research, the TOT and POT are most relevant, as SMEs are typically privately held. Our empirical tests will therefore focus on these two theories.
Table 1 Capital structure theory and expected sign on leverage for explanatory variables

\begin{tabular}{lll}
\hline & $\begin{array}{l}\text { Trade-off } \\
\text { theory }\end{array}$ & $\begin{array}{l}\text { Pecking-order } \\
\text { theory }\end{array}$ \\
\hline Firm characteristics & & + \\
Firm size & + & + \\
Collateral & + & - \\
Profitability & + & + \\
Growth opportunities & - & \\
Industry characteristics & & $?$ \\
Fixed effects & Significant & \\
\hline
\end{tabular}

\subsection{Leverage factors}

We discuss subsequently the firm and industry determinants of leverage as well as their relation to both capital structure theories. We summarize the predictions in Table 1 and formulate explicit hypotheses.

\subsubsection{Firm characteristics}

Firm size is considered as an inverse proxy of bankruptcy costs. The TOT predicts a positive relationship between firm size and leverage, because size is assumed as a proxy for earnings volatility and larger firms are generally more diversified and show less volatility (Fama and French 2002). Less volatile earnings reduce indirect bankruptcy costs such that firms can take on more debt. The POT also predicts a positive relationship between firm size and leverage, because more diversification and less volatile earnings mitigate problems of asymmetric information. This decreases the costs of debt compared with other sources of finance. Several empirical studies find a positive relationship for both large firms and SMEs (Van Dijk 1997; De Jong 1999; Fama and French 2002; Michaelas et al. 1999; Cassar and Holmes 2003; Sogorb-Mira 2005; Hall et al. 2004). Our first empirical proposition (or hypothesis) based on the TOT and POT is:

\section{Proposition P1 Larger firms have higher leverage.}

The effect of firm size on short-term debt has been empirically verified by several authors. Michaelas et al. (1999) and Hall et al. (2004) report a negative effect, even though the effect on total leverage is positive. Sogorb-Mira (2005) finds similar effects for 
total debt but no significant effects of firm size on short-term debt. Ortiz-Molina and Penas (2006) find that size increases the maturity of lines of credit. The high business risk and informational opacity increase if firms are smaller. Small firms then have to rely more on short-term debt. We therefore formulate the following two propositions based upon previous empirical work:

Proposition P1a Firm size is positively related to long-term debt.

\section{Proposition P1b Firm size is negatively related to} short-term debt.

The firm's asset structure is a second factor determining capital structure. Asset tangibility is expected to be positively correlated with debt, as it provides collateral. Collateral reduces agency problems with debtholders and reduces bankruptcy costs and credit risk. Therefore, the TOT predicts a positive relationship between collateral and leverage. Collateral also mitigates information asymmetry problems such that also the POT implies a positive correspondence. De Jong (1999) confirms the positive relationship between tangible assets and leverage, whereas Titman and Wessels (1988) report a negative, though not statistically significant, relationship. The information asymmetry argument is particularly relevant for SMEs, as they are more opaque than large firms. Small firms often do not have to provide (audited) financial statements or do not issue traded securities. For these reasons, collateralized lending is important for SMEs. Michaelas et al. (1999) and Sogorb-Mira (2005) find a positive effect of tangible assets on leverage for SMEs. Hall et al. (2004) report a small positive relationship for Dutch SMEs. Therefore, our proposition regarding asset structure is:

Proposition P2 Collateral has a positive effect on debt ratio.

Collateral may affect short-term and long-term debt differently. Previous work documents a negative relationship for short-term debt and a positive one for long-term debt (Van der Wijst and Thurik 1993; Michaelas et al. 1999; Hall et al. 2004; Sogorb-Mira 2005). Ortiz-Molina and Penas (2006) argue that collateral and maturity are substitutes in reducing agency problems. We therefore supplement proposition 2 with:
Proposition P2a Collateral has a stronger positive effect on long-term debt than on short-term debt.

Liquidity is a second dimension of a firm's asset structure. Illiquid firms are restricted in attracting debt, as bankruptcy costs are high. The TOT then predicts a positive relationship between liquidity and leverage. We employ "net debtors" as a proxy for liquidity. It is particularly relevant for SMEs because small firms generally put less pressure on collecting payments from customers. Late payments are often financed by trade credit. In the pecking order, trade credit may be on top of the preference list. Suppliers grant trade credit as they may have superior information compared with banks regarding their customers' liquidity. This alleviates problems of asymmetric information (Berger and Udell 2006). Of course, firms cannot delay late payments to creditors beyond a certain point. It can therefore be expected that short-term debt increases if a firm suffers from late payments. Michaelas et al. (1999) report positive coefficients of net debtors on short-term and longterm debt, although the effect on long-term debt was negligible. These results give rise to the next propositions:

Proposition $\mathbf{P 3}$ Net debtors is positively related to the debt level.

Proposition P3a Net debtors has a stronger positive relationship with short-term debt than with longterm debt.

Profitability is another determinant of capital structure. The free cash flow theory of Jensen (1986) states that more debt disciplines the manager if profits increase. A positive relationship between debt and profitability is then expected. The POT predicts the opposite effect of profitability on leverage. Retained earnings are on top of the preference list to finance investments, so higher profits reduce the necessity to raise debt. Studies using large-company data find a negative relationship between debt and profitability (Titman and Wessels 1988; Van Dijk 1997; Fama and French 2002). The POT also applies to SMEs, whereas agency conflicts between managers and shareholders should be less relevant (see also Ang 1992). Studies on SMEs also find a negative impact of profitability on debt (Van der Wijst and Thurik 1993; Michaelas et al. 1999; 
Sogorb-Mira 2005). Therefore, our next proposition is:

\section{Proposition P4 Profitability is negatively related to leverage.}

Profitability may differentially impact short-term and long-term debt. Michaelas et al. (1999) find a larger effect of profitability on long-term debt compared with short-term debt. They argue that SMEs prefer short-term financing and that long-term debt will be reduced if internal funding is available. On the other hand, short-term debt can be amortized more easily and carries higher interest rates. This suggests a stronger influence on short-term debt, which is validated by several SME studies (Van der Wijst and Thurik 1993; Cassar and Holmes 2003; Sogorb-Mira 2005). Therefore, proposition P4 is supplemented as follows:

Proposition P4a Profitability has a greater negative impact on short-term debt than on long-term debt.

Agency problems between managers and debtholders are particularly relevant for firms with growth opportunities. Myers (1977), for example, argues that managers underinvest because equity holders may not earn a profit on some projects with positive net present value (NPV) if interest payments are high. The TOT predicts a negative relationship between growth opportunities and leverage. Myers (1977), however, models that short-term debt could overcome the underinvestment problem and therefore is positively affected by growth opportunities. According to the POT, growth opportunities and leverage are expected to be positively related. Firms with growth opportunities are more likely to raise new funds than are firms without growth possibilities (De Jong 1999). Growth opportunities for larger or publicly listed firms are proxied by research and development (R\&D) expenses, the market-to-book ratio or intangible assets. Titman and Wessels (1988), Fama and French (2002), and Graham and Harvey (2001) report a negative relationship between their proxies of growth opportunities and leverage. Another explanation for a negative link is that assets needed for future growth are poor collateral. Studies on SMEs find evidence for a positive relationship of leverage with growth opportunities. Growth opportunities in these studies are proxied by intangible assets or growth in sales or assets. Sogorb-Mira (2005) reports a stronger positive effect on long-term debt, but a negative impact on short-term debt. Michaelas et al. (1999) find a positive impact on short-term debt.

\section{Proposition P5 Growth opportunities positively relate to leverage.}

We also briefly discuss expected impacts from taxation. Modigliani and Miller (1963) argue that firms prefer debt financing because of the tax shield, so a positive relationship between the tax rate and leverage can be expected. Studies focusing on SMEs, however, find a negative relationship for SMEs and argue that the tax status of a company is not informative. Sogorb-Mira (2005) show that SME managers choose other instruments to lower their tax payments, whereas Jordan et al. (1998) claim that taxes lower retained earnings. The total tax burden of a firm is not solely determined by the tax rate but by taxable income as well. Some authors argue that this is even more important than testing the tax rate itself (Van Dijk 1997). Interest payments reduce taxable income, but other items can do the same. These nondebt tax shields could substitute for the tax shield of debt (Titman and Wessels 1988). Hence, a negative relationship with debt ratio is expected. In the empirical section below, we also test for tax effects, but we do not formulate an explicit proposition.

\subsubsection{Industry characteristics}

We now turn to formulating explicit propositions on industry effects. We first focus on inter-industry effects. The TOT posits that firms target an optimal leverage ratio, and this optimal leverage may differ across industries. This can be captured by industry fixed effects. The POT, in contrast, does not deliver a clear prediction with respect to industry fixed effects. However, to the extent that there are unobservable factors that are correlated within an industry, then also industry fixed effects could be significant (see also Cole 2008). Finally, the TOT and the POT could also be of differential importance across industries. For example, the degree to which propositions P1$\mathrm{P} 5$, particularly propositions $\mathrm{P} 4$ and P5, apply may be different. The empirical investigation of inter-industry effects deals with the question of the extent to which capital structure variation between firms is 
explained by industry characteristics compared with firm characteristics. Balakrishnan and Fox (1993), for example, find that $52 \%$ of capital structure variation is explained by firm effects and $11 \%$ by inter-industry differences. MacKay and Phillips (2005) report similar percentages for firm and inter-industry effects. Michaelas et al. (1999) use industry fixed effects to test whether industry effects have an influence on SME capital structure. They find significant industry fixed effects, but the impacts are primarily on short-term debt. We therefore formulate the following two propositions:

Proposition P6 Industry fixed effects are significant determinants of leverage.

Proposition P7 The relevance of empirical propositions P1-P5 differs across industries.

Next to heterogeneity across industries, leverage could also exhibit intra-industry heterogeneity. This may be driven, for example, by industry competition, the degree of agency conflicts, and the heterogeneity in employed technology. The degree of competition, for example, determines whether a firm is close to the optimal degree of leverage within an industry. In particular, in industries with low competition, firms face less pressure to be close to the optimal target, whereas in industries with high competition, firms can only survive by choosing the optimal degree of leverage in order to minimize costs (Leibenstein 1966; MacKay and Phillips 2005). Agency conflicts resulting from conflicting objectives between shareholders and managers may determine firms' capital structures; for example, managers could choose too low debt ratios in order to protect their human capital (Fama 1980) or to avoid pressure from interest payments (Jensen 1986). Managers may take on too much leverage in order to signal their quality or to decrease takeover attempts (e.g., Harris and Raviv 1991 or Stulz 1988). We then expect that, in industries without agency conflicts, there should be less leverage dispersion. Finally, Maksimovic and Zechner (1991) model that industries with more technological dispersion exhibit more capital structure dispersion. We do not formulate a hypothesis on intra-industry effects, as our dataset only contains limited information on competition, technological dispersion, or agency problems within an industry.

\section{Description of the data and research methodology}

\subsection{Dataset}

Our dataset has been kindly provided by Rabobank, a large Dutch financial institution. The database contains financial statements of the bank's SME clients. Many clients, particularly if they have a loan, are required to provide a detailed balance sheet and income statement every year. A potential concern is that our data is self-selected, as it comes from one bank only. We believe that the dataset is highly representative for the Dutch setting for several reasons. First, Rabobank is the largest player in this SME segment with a market share of 39\% (in 2008) and is active in all industries and provinces. This should reduce the potential for selection issues to impact on our sample. It is also important to mention that, when firms have relationships with several banks, including Rabobank, these firms are part of the dataset. This further increases the relevance of the dataset at hand. Second, one could argue to use a publicly available dataset based on Amadeus (i.e., REACH). We compared the descriptive statistics of REACH with those of our dataset and find that our dataset contains relatively more small firms, as it includes information on firms which by law do not have to submit detailed balance sheet data. Therefore, this self-selected sample allows greater learning about the capital structure of small firms in comparison with using REACH.

Firms are included in the dataset when they have less than $€ 20$ million annual sales over the period 2002-2005, and when they report to the bank at least two annual accounts within this period. ${ }^{1}$ We therefore have an unbalanced panel. While the bank is active in all industries, the dataset does not contain firms active within the agricultural sector or the energy and utilities sector. Additionally, we removed financial firms as is common in capital structure studies, as financial institutions face regulatory capital requirements and may inherently have a different capital structure. Moreover, associations (e.g., sport clubs, political organizations, labor unions) were removed, because they do not have commercial activities and

\footnotetext{
${ }^{1}$ In the analysis, all observations for 2002 were lost because they were needed to calculate the growth variable, as discussed below.
} 
Table 2 Descriptive statistics

\begin{tabular}{|c|c|c|c|c|c|}
\hline & Definition & Mean & Std. dev. & Min & Max \\
\hline \multicolumn{6}{|c|}{ Dependent variables } \\
\hline Total debt & total debt/total assets & 0.492 & 0.246 & 0 & 1.659 \\
\hline Long-term debt & long-term debt/total assets & 0.308 & 0.252 & 0 & 1.452 \\
\hline Short-term debt & short-term debt/total assets & 0.184 & 0.162 & 0 & 0.993 \\
\hline \multicolumn{6}{|l|}{ Firm characteristics } \\
\hline Size $(\log )$ & $\log$ of total assets & 6.045 & 1.318 & 0.693 & 9.171 \\
\hline Tangible assets & tangible fixed assets/total assets & 0.487 & 0.288 & 0 & 1 \\
\hline Net debtors & (debtors - creditors)/total assets & 0.046 & 0.146 & -0.534 & 0.587 \\
\hline ROA & EBITD/total assets & 0.153 & 0.322 & -14.00 & 7.286 \\
\hline Intangible assets & intangible assets/total assets & 0.017 & 0.066 & -0.308 & 1 \\
\hline Growth (assets) & {$[$ tot. $\operatorname{assets}(t)-$ tot. $\operatorname{assets}(t-1)] /$ tot. $\operatorname{assets}(t-1)$} & 0.133 & 0.437 & -0.599 & 3.300 \\
\hline Tax rate & taxes paid/earnings before tax & 0.094 & 0.173 & -0.362 & 0.771 \\
\hline Depreciation & depreciation expense/total assets & 0.179 & 0.070 & 0 & 1 \\
\hline \multicolumn{6}{|l|}{ Industries } \\
\hline Manufacturing, $\mathrm{c}$ & tion, wholesale trade, retail trade food, retail trac & ood, & $g$ and le & anspor & ices \\
\hline
\end{tabular}

Notes: The amount of taxes paid is not directly observed. The amount is derived by multiplying the return on equity (which is based on profits after tax) by the amount of equity. This gives profits after taxes. Deducting this from profits before tax gives an implied measure of taxes paid. Bank-strategic reasons prevent us from reporting the descriptive statistics on specific industries. ROA, return on assets; EBITD, earnings before interest, taxes, and depreciation

often rely on governmental funding. Finally, we removed all entries with data errors, or which take values which are unreasonable on economic grounds, and drop observations with extreme values such as very large firms. Our final dataset contained 99,031 firm-year observations. The number of observations in 2005 decreased substantially (by more than $30 \%$ ) compared with 2003 and 2004. This stems from the collection efforts by the bank. From 2005 onwards they started to rely more on REACH, making the 2005 dataset more comparable to that dataset. We investigate the robustness of this in Sect. 4.3 below.

We employ different proxies for capital structure. The most commonly used measure is total debt ratio, i.e., the relative amount of debt (leverage), defined as total debt over total assets. We also consider the short-term and long-term debt ratio separately. Definitions and descriptive statistics are presented in Table 2. Debt is measured by its book value. Market values are not known for SMEs, such that most SME managers have to base their financing decisions on book values. For short-term debt, we include bank loans and other short-term debt. ${ }^{2}$ Following other

\footnotetext{
${ }^{2}$ In a previous version of the paper we employed only shortterm bank debt. The empirical results were qualitatively similar.
}

studies, we excluded trade credit as it does not carry an explicit interest rate and is under the influence of completely different determinants (for example, de Jong et al. (2008) focus for that reason only on longterm debt in their cross-country analysis of the determinants of capital structure, and do entirely drop short-term debt).

Table 2 shows that Dutch SMEs have more longterms loans than short-term loans $(63 \%$ of total debt is long-term debt). These numbers are in contrast to those of Hall et al. (2004), who report an average long-term debt level of 2\% for Dutch SMEs. This difference can be explained as follows. The long-term debt definition in our dataset is based upon loans given with a long maturity but not necessarily a long duration. That is, some short-term loans may be classified as long-term debt as the debt is given within the framework of a line of credit but with a revisable loan rate. We further checked with previous work that focused on the capital structure of Dutch firms. For example, Chen et al. (1999) report a longterm to total credit ratio of $77 \%$. Our numbers are in the same ballpark, showing that the Hall et al. (2004) results on short-term versus long-term debt should be seen as an outlier. The descriptive statistics in Table 2 also differ from those of other countries. 
Sogorb-Mira (2005) reports for Spanish SMEs that $15 \%$ of total debt is long-term debt, and Michaelas et al. (1999) find for UK SMEs that the ratio is $29 \%$.

Table 2 also provides descriptive statistics on our determinants of capital structure: firm size, tangible fixed assets, net debtors, profitability, intangible assets, asset growth, effective corporate tax rate, depreciation, and industry characteristics. Firm size is measured as the log of total assets. A measure for asset structure is tangible assets. Tangible assets are all fixed assets except intangible fixed assets and inventories (Titman and Wessels 1988; Sogorb-Mira 2005). As opposed to real estate and equipment, inventories are short-term assets and therefore expected to be poor collateral. Net debtors is measured by the difference between debtors and creditors, scaled by total assets (Michaelas et al. 1999). Table 2 shows that the firms in our sample have much more tangible than intangible assets. In addition, on average, net debtors is small. To measure the effect of profitability, we use return on assets (ROA), which is defined as earnings before interest, taxes, and depreciation (EBITD) scaled by total assets. The profit numbers of nonincorporated business are corrected for an owner's wage. ${ }^{3}$ Depreciation is not deducted in all empirical studies, but if the aim is to test how managers change their debt position with profits, managers will very likely take into account the cash position. Moreover, depreciation is already used as a measure for nondebt tax shield. The proxy for growth opportunities is intangible assets scaled by total assets (Michaelas et al. 1999; Sogorb-Mira 2005). Intangible assets refer to assets that are expected to pay off in the future, such as brand names, goodwill, or research and development expenses. Current growth is measured by the relative yearly change in total assets, implying that the first year of our analysis becomes 2003. We have data on eight industries. Bank-strategic reasons however prevent us from reporting descriptive statistics on those industries.

The effective corporate tax is measured as the amount of company taxes divided by the profit before tax. This variable is not scaled by total assets, since the amount of taxes depends on profits. Nondebt tax shields lower taxable income and can therefore

\footnotetext{
${ }^{3}$ Net profit (before tax) of nonincorporated firms has been adjusted with a proxy for the average Dutch income for a small business director, which is $€ 40,000$.
}

substitute for the tax benefits of debt. Titman and Wessels (1988) introduced depreciation as a proxy for nondebt tax shields, but did not find significant effects. A problem with depreciation as a proxy for nondebt tax shields is that it can also be an indicator for fixed assets. Van Dijk (1997) reported a high correlation (i.e., 0.495) between depreciation and fixed assets. Since he finds a significant negative relationship between depreciation and leverage, he argues that it is unlikely that a firm's collateral value (for which depreciation can be a proxy as well) has a positive influence on leverage. Nevertheless, depreciation was used in many other empirical studies (e.g., Fama and French 2002; Sogorb-Mira 2005).

Table 3 shows the correlations between all variables of interest. As expected, there is a large correlation between long-term debt and total debt. In addition, the highest correlation is between long-term debt and tangible assets, suggesting that long-term debt goes together with physical collateral. Tangible assets and intangible assets exhibit a slightly negative correlation $(-0.185)$, suggesting that they are (weak) substitutes. The other correlations are quite low, showing that multicollinearity is not a concern.

\subsection{Econometric model}

We employ panel data analysis, as our dataset includes observations over several years. Some firms appear twice, while others appear for all 4 years, which makes the dataset unbalanced. We index all variables with an $i$ for the individual $(i=1, \ldots, N)$ and a $t$ for the time period $(t=1, \ldots, T)$. Depending upon our model below, the individuals $i$ may be firms or industries. The general static panel data regression model can then be written as

$y_{i t}=\beta_{0}+x_{i t}^{\prime} \beta+\varepsilon_{i t}, \quad i=1, \ldots, N$ and $t=1, \ldots, T$,

where $x_{i t}$ is a $K$-dimensional vector of explanatory variables, which does not contain an intercept term. This model imposes that the intercept $\beta_{0}$ and the slope coefficients in $\beta$ are identical for all individuals (i.e., firms or industries) and time periods.

A frequently employed panel data model assumes that $\varepsilon_{i t}=\alpha_{i}+u_{i t}$, where $\alpha_{i}$ denotes the unobservable individual-specific effect (i.e., industry or firm) that is time invariant, and $u_{i t}$ is the random error. In our 
Table 3 Correlations among variables employed in regressions

\begin{tabular}{|c|c|c|c|c|c|c|c|c|c|c|}
\hline & $\begin{array}{l}\text { Total } \\
\text { debt }\end{array}$ & $\begin{array}{l}\text { Long-term } \\
\text { debt }\end{array}$ & $\begin{array}{l}\text { Short-term } \\
\text { debt }\end{array}$ & $\begin{array}{l}\text { Size } \\
(\log )\end{array}$ & $\begin{array}{l}\text { Tangible } \\
\text { assets }\end{array}$ & $\begin{array}{l}\text { Net } \\
\text { debtors }\end{array}$ & ROA & $\begin{array}{l}\text { Intangible } \\
\text { assets }\end{array}$ & $\begin{array}{l}\text { Growth } \\
\text { (assets) }\end{array}$ & $\begin{array}{l}\text { Tax } \\
\text { rate }\end{array}$ \\
\hline Long-term debt & 0.787 & & & & & & & & & \\
\hline Short-term debt & 0.293 & -0.359 & & & & & & & & \\
\hline Size $(\log )$ & 0.101 & 0.114 & -0.023 & & & & & & & \\
\hline Tangible assets & 0.389 & 0.604 & -0.346 & 0.034 & & & & & & \\
\hline Net debtors & -0.046 & -0.157 & 0.174 & -0.033 & -0.182 & & & & & \\
\hline ROA & -0.064 & -0.060 & -0.004 & 0.033 & -0.063 & 0.177 & & & & \\
\hline Intangible assets & 0.050 & 0.025 & 0.038 & 0.042 & -0.185 & -0.004 & 0.031 & & & \\
\hline Growth (assets) & 0.016 & 0.020 & -0.007 & 0.035 & -0.047 & 0.017 & 0.026 & 0.018 & & \\
\hline Tax rate & -0.111 & -0.182 & 0.114 & 0.427 & -0.225 & 0.129 & 0.023 & 0.090 & 0.017 & \\
\hline Depreciation & 0.049 & 0.011 & 0.058 & -0.347 & 0.154 & 0.047 & 0.155 & 0.091 & -0.178 & -0.123 \\
\hline
\end{tabular}

empirical analysis we assume a fixed-effects model for the unobservable individual effects for two reasons. First, the fixed-effects model introduces an individual-specific intercept term (i.e., firm specific or industry specific) that could capture specific entrepreneurial skills or industry-specific factors. Berger and Udell (2006), for example, argue that the management capabilities of the entrepreneur are a crucial factor in SME financing. We follow the approach of several SME capital structure studies which also use a fixed-effects panel data model (Van der Wijst and Thurik 1993; Michaelas et al. 1999; Sogorb-Mira 2005). Second, the nature of the unobserved effects has been statistically verified with a (not reported) Hausman test. This test rejects the null hypothesis that the explanatory variables and the individual effects (i.e., firm or industry) are uncorrelated. A fixed-effects model can cope with correlation between explanatory variables and individual effects (i.e., firm or industry) and therefore it is statistically preferred (see also Verbeek 2008, pp. 367-369).

\section{Empirical results}

Section 4.1 discusses the results on the firm characteristics as drivers of capital structure, using the entire sample pooling all industries. The results of the industry characteristics are discussed in Sect. 4.2. Section 4.3 investigates the issue of limited liability and summarizes the results of several robustness checks.

\subsection{Firm characteristics}

The results of panel data regressions for total debt, long-term debt, and short-term debt are reported in Table 4. All regressions include seven industry fixed effects to which we turn in Sect. 4.2.

In all models, most of the individual variables are statistically significant. The estimates presented in Table 4 confirm proposition P1, as larger firms exhibit higher leverage. A one standard deviation change in log size implies a 3.03 percentage point increase in the ratio of total debt to total assets. Proposition P3a is confirmed as well: the coefficient for size in the long-term debt regression is positive, statistically significant, and economically relevant. Proposition P3b is rejected, as firm size appears with a significant positive coefficient in the short-term debt regression. Its economic relevance, however, is very small. These results show that larger firms rely more on long-term finance and less on short-term finance. The results on total debt and long-term debt are in line with previous studies on SMEs (see, for example, Van der Wijst and Thurik 1993 and SogorbMira 2005). Larger firms are more aware of better financing methods, since they employ more financial and administrative staff and may have a stronger bargaining position towards lenders.

Strong support is found for proposition P2 concerning the positive relationship between total debt and collateral. A one standard deviation increase in tangible assets implies a 10.08 percentage point increase in the ratio of total debt to assets. The 
Table 4 Industry fixed-effects panel regressions with firm characteristics

\begin{tabular}{|c|c|c|c|c|c|c|}
\hline & \multicolumn{2}{|c|}{ Total debt } & \multicolumn{2}{|c|}{ Long-term debt } & \multicolumn{2}{|c|}{ Short-term debt } \\
\hline & Estimate & Std. error & Estimate & Std. error & Estimate & Std. error \\
\hline \multicolumn{7}{|l|}{ Firm characteristics } \\
\hline Size $(\log )$ & $0.023 *$ & 0.0029 & $0.019 *$ & 0.0024 & $0.004^{*}$ & 0.0015 \\
\hline Tangible assets & $0.350 *$ & 0.0278 & $0.546^{*}$ & 0.0148 & $-0.195^{*}$ & 0.0170 \\
\hline Intangible assets & $0.486^{*}$ & 0.0449 & $0.631 *$ & 0.0456 & $-0.145^{*}$ & 0.0224 \\
\hline Net debtors & $0.161 *$ & 0.0353 & 0.021 & 0.0114 & $0.140^{*}$ & 0.0346 \\
\hline ROA & $-0.040 *$ & 0.0155 & -0.006 & 0.0047 & $-0.034^{*}$ & 0.0113 \\
\hline Growth (assets) & $0.024 *$ & 0.0050 & $0.022 *$ & 0.0029 & 0.002 & 0.0055 \\
\hline Tax rate & $-0.109 *$ & 0.0281 & $-0.141 *$ & 0.0255 & $0.032^{*}$ & 0.0097 \\
\hline Depreciation & 0.070 & 0.0517 & $-0.287 *$ & 0.0239 & $0.357^{*}$ & 0.0371 \\
\hline \multicolumn{7}{|l|}{ Industry fixed effects } \\
\hline Manufacturing & Omitted & & Omitted & & Omitted & \\
\hline Construction & $-0.034 *$ & 0.0026 & $-0.024 *$ & 0.0014 & $-0.009 *$ & 0.0013 \\
\hline Wholesale trade & $0.014 *$ & 0.0043 & 0.002 & 0.0022 & $0.012^{*}$ & 0.0030 \\
\hline Retail trade food & $0.036 *$ & 0.0056 & $0.019 *$ & 0.0024 & $0.017 *$ & 0.0045 \\
\hline Retail trade nonfood & $0.076^{*}$ & 0.0086 & $0.056^{*}$ & 0.0031 & $0.020^{*}$ & 0.0069 \\
\hline Catering and leisure & 0.009 & 0.0059 & $0.008 *$ & 0.0036 & 0.001 & 0.0033 \\
\hline Transport & $0.017^{*}$ & 0.0063 & $0.021 *$ & 0.0036 & -0.003 & 0.0042 \\
\hline Services & $-0.009 *$ & 0.0007 & $-0.022 *$ & 0.0003 & $0.012^{*}$ & 0.0006 \\
\hline$R^{2}$ & 0.202 & & 0.422 & & 0.156 & \\
\hline
\end{tabular}

Notes: This table provided the estimation results for Eq. 3.1 using the complete sample. * Significant at the 5\% level. Variable definitions are presented in Table 2

interpretation of a change is such that it is induced by the numerator and that total assets as a scaling variable remains unaffected. Collateral is very important for SMEs, since it helps to overcome informational problems. The positive effect on total debt stems entirely from long-term debt, as short-term debt is negatively affected by collateral, partly confirming proposition P2a. Since collateral is a way to mitigate risk of SMEs, these firms can fully use their collateral to attract long-term debt. For the firm, the costs of long-term debt are lower because banks charge (relatively) higher interest rates on short-term loans. These findings are in accordance with the maturity-matching principle that long-term assets are financed with long-term financing and short-term assets are financed with short-term funds.

There is also strong support for propositions P3 and P3a. Net debtors, financed with both long-term and short-term debt, positively affect the total debt level. Firms with low net debtors have lower debt ratios (ceteris paribus). A one standard deviation decrease in net debtors lowers the debt ratio by about 2.4 percentage points. The empirical results show that the effect is only statistically significant and positive for short-term debt. This also provides evidence for the maturity-matching principle.

Profitability is negatively related to the total debt ratio, and this supports proposition $\mathrm{P} 4$. A one standard deviation increase in ROA lowers the total debt ratio by 1.3 percentage points. Debt levels are lower if a firm generates profits. This suggests that SME managers prefer internal financing first, as predicted by the POT. The most likely reason is that they want to stay in control and avoid debt as much as possible (Vos et al. 2007). This result shows that the agency problem of free cash flow is nonexistent in SMEs, because they do not have public equity and typically ownership is concentrated. We investigate this further in Sect. 4.3. The negative relationship between profitability and debt is only significant for shortterm debt, providing support for proposition P4. This finding is consistent with previous studies by Van der 
Wijst and Thurik (1993), Cassar and Holmes (2003), and more recently Sogorb-Mira (2005) for Spanish data. Short-term debt can be amortized easily.

Support for proposition P5 on growth opportunities is provided, as firms with more intangible assets have a greater total debt ratio: a one standard deviation increase implies a 3.2 percentage point increase in total debt ratio. The agency theory of Myers (1977) is therefore not supported by the results for growth opportunities. Support for the POT, however, is provided by the results of growth opportunities and asset growth. Firms with a lot of intangible assets have less short-term debt and are very well able to finance their future growth with long-term debt. It is, however, important to note that many firms in the database have no intangible assets on their balance sheet (Table 2). Also comparing economic relevance, tangible assets seem more important. The results for asset growth do not change the conclusion drawn for proposition P5. The coefficients on asset growth are low, but a positive effect of asset growth on long-term debt is found. Therefore, our empirical results support proposition P5, which is in line with Michaelas et al. (1999). In the period under investigation (2003-2005) the average total assets per firm increased. The growth in total assets is mainly due to an increase in fixed assets, which implies that firms invested more and could attract external financing for this. However, in the same period, interest rates have declined, making it likely that firms used that opportunity to opt for long-term loans. Unfortunately, the effect of loan rates cannot be studied more in depth due to lack of detailed data.

The results in Table 4 indicate that the tax rate has a significant negative effect on total and long-term debt, but a slightly positive effect on short-term debt. In particular the results imply that a one standard deviation increase in tax decreases the long-term debt ratio of SMEs by 2.4 percentage points (ceteris paribus), while the short-term debt ratio increases by 0.45 percentage points (ceteris paribus). This finding is in line with Michaelas et al. (1999), who also report negative but small effects of taxes. A possible explanation is that high taxes stem from high profits, which in turn decreases the need for debt (Jordan et al. 1998). The second measure of the tax effect, i.e., depreciation, is not significant for total debt. It shows a significant positive coefficient for short-term debt and a negative coefficient for long-term debt.

\subsection{Investigating industry effects}

We first focus on inter-industry differences and test proposition P6. The bottom panel of Table 4 reveals that all industry dummies are significant. This shows that all industries have a different capital structure compared with manufacturing, which is our base case. This holds for total debt, long-term debt, as well as short-term debt, providing support for proposition P6. These results show that differences in firm characteristics cannot explain all differences between industries for SMEs. In other words, this is evidence that some other characteristics of an industry are important determinants of the SME debt ratio. The industries with the strongest fixed effects are retail trade nonfood and food, with 7.6 and 3.6 percentage points greater total debt ratio than the base case. These industries have a leverage ratio that is above average, while important firm characteristics such as profitability and collateral are below average. The retail food industry is known for its low equity ratio, since it is an extremely competitive industry. This is probably the reason why higher debt ratios are observed. The construction sector exhibits the lowest total debt ratio. Interestingly, the results also show that there is a fixed industry effect that differs in sign between long-term and short-term debt for the catering and leisure, and transport sectors.

In order to test proposition P7, we estimate a model for each industry separately. We now include both firm fixed effects and firm characteristics. These industry sample regressions compute a coefficient for each firm characteristic per industry (results are presented in Table 6 in the Appendix). Before turning to the heterogeneity in coefficients on our firm characteristics, we mention that almost all the conclusions regarding the hypotheses are the same for all industries individually, suggesting that the POT is most relevant for all industries studied. To test proposition $\mathrm{P} 7$, we then investigate whether there is significant cross-sectional variation in the estimated coefficient for each firm characteristic. The standard deviation of the cross-section of the individual estimates for the eight different industries is used as a measure for this variation. This helps us to investigate whether the relevance of 
Table 5 Industry effects and leverage: variation of parameter estimates across industries

\begin{tabular}{llll}
\hline & $\begin{array}{l}\text { Total debt } \\
\text { St. dev. of estimates }\end{array}$ & $\begin{array}{l}\text { Long-term debt } \\
\text { St. dev. of estimates }\end{array}$ & $\begin{array}{l}\text { Short-term debt } \\
\text { St. dev. of estimates }\end{array}$ \\
\hline Size (log) & $0.012^{*}$ & $0.008^{*}$ & $0.006^{*}$ \\
Tangible assets & $0.084^{*}$ & $0.055^{*}$ & $0.047^{*}$ \\
Intangible assets & $0.117^{*}$ & $0.068^{*}$ & $0.099^{*}$ \\
Net debtors & $0.088^{*}$ & $0.069^{*}$ & $0.096^{*}$ \\
ROA & $0.062^{*}$ & $0.034^{*}$ & $0.039^{*}$ \\
Growth (assets) & $0.014^{*}$ & $0.010^{*}$ & $0.008^{*}$ \\
Tax rate & $0.091^{*}$ & $0.091^{*}$ & 0.032 \\
Depreciation & 0.132 & $0.065^{*}$ & $0.098^{*}$ \\
\hline
\end{tabular}

Notes: This table presents the standard deviation of the estimates for eight industries as reported in the Appendix. The Wald tests indicate whether the individual estimates are the same across industries. * Significant at the $5 \%$ level. Definitions of all variables are presented in Table 2

propositions P1-P5 differs across industries. In other words, it allows us to investigate which capital structure theories are most relevant for which industries. Table 5 presents the estimates for the variation measure as well as the results for the individual Wald tests. These tests investigate whether all the coefficients for a firm characteristic are equal across industries. If the Wald test hypothesis is rejected, the relationship is different for at least one industry.

The Wald test indicates that, for most firm characteristics, the relationship with the debt level varies significantly across industries. This variation is most pronounced and significant for net debtors, tangible assets, intangible assets, tax rate, and profitability. We are most interested in the results for profitability and intangible assets, as these are related to propositions $\mathrm{P} 4$ and $\mathrm{P} 5$, respectively. The reason is that the TOT and POT have opposite predictions. Table 6, in the Appendix, shows that the coefficient on profitability is only positive for the catering and leisure sector. This suggests that the pecking-order theory dominates for the other seven sectors, whereas the TOT dominates for the catering and leisure sector. The effect of profitability on leverage is particularly negative in the wholesale trade, retail trade food and nonfood, and transport sectors, suggesting that the POT dominates more for these sectors. Also note that the retail trade food sector is the only industry in which the effect on longterm debt is larger than on short-term debt: profits reduce long-term debt more than short-term debt. The coefficient on intangible assets is positive for all sectors, suggesting that proposition P5 applies for all sectors. In other words, the POT dominates the TOT for all sectors. The coefficient on intangible assets is largest for the transport sector.

Finally, we investigate the role of intra-industry characteristics. We evaluate this by considering the impact of the firm fixed effects on the $R^{2}\left(R^{2}\right.$ firm fixed effects versus $R^{2}$ pooled) for the regressions studying the different industries separately. A reading of the results in the Appendix shows two important results. First, firm fixed effects are important in all industries, suggesting that within-industry heterogeneity is important. As the $F$-tests clearly show, the null hypothesis that all firm fixed effects are equal to zero is rejected at all conventional significance levels for all industries. These $F$-tests take into account the difference in degrees of freedom between the firm fixed-effects model and the pooled regression model. Second, the values of the $F$-tests are highest for the retail trade nonfood and transport industries, which implies the largest increase in $R^{2}$ (corrected for the difference in degrees of freedom) after adding the firm fixed effects. This indicates that, within these industries, firm fixed effects which pick up the individual variability in leverage ratios are very important. This shows that industry competition, the degree of agency conflicts, and the heterogeneity in employed technology are important drivers of capital structure. Unfortunately, as our dataset only contains limited information on competition, technological dispersion, or agency problems within an industry, we cannot further explore this issue and leave this for future research. 


\subsection{Limited liability and robustness checks}

The dataset provides us with information on whether a firm has limited-liability protection or not. Based on Cole (2008), we expect that firms with limitedliability protection have higher leverage than otherwise similar firms. Such protection may also partly capture a decrease in ownership concentration compared with sole proprietorships, for example. To conserve space, we briefly discuss our findings without reporting them in tables.

When adding a dummy for limited liability to the specifications reported in Table 3 , we find that it is not significant for total debt, positive for short-term debt, and negative for long-term debt. This suggests that limited liability only increases the degree of short-term leverage. This is in contrast with the results in Cole (2008), where he finds that limitedliability firms exhibit higher total leverage (he does not investigate short- and long-term debt separately). We further investigated whether the firm and industry effects differ between limited-liability firms or not, by interacting all explanatory variables with the limited-liability dummy. We find that the coefficients on the firm characteristics are different for limitedliability firms. In particular, total debt of limitedliability firms is less exposed towards firm size, and tangible and intangible assets. In addition, both short term and long term debt of limited liability firms are less exposed towards tangible and intangible assets. This suggests that limited-liability firms have different means of raising capital for (future) investments or running their business, which is in line what we expect for those types of firms.

We now briefly summarize the results of four robustness checks. First, as indicated above, 2005 contains about $30 \%$ fewer observations than the other years. We investigated whether the results for 2005 were different from those in other years by running a model where we included interaction terms of all firm characteristics with a 2005 dummy. We found that almost all the interaction terms were insignificant. Using a Wald test, the null hypothesis that the coefficients of all 2005 interaction terms were jointly zero could not be rejected. This indicates that our results are robust to the reduction in the number of observations. The second robustness check concerns the maturity-matching principle. This principle states that short-term assets are financed with short-term assets. In unreported regressions, we add the variable inventories, another short-term asset, to our specifications of Sect. 4.1. Previous studies such as Titman and Wessels (1988) and Michaelas et al. (1999) consider inventories as tangible fixed assets, but if the maturity-matching principle is true, inventories should positively relate to short-term debt and have no significant relationship with long-term debt, since inventories are a short-term asset. We find that the coefficients for inventories are significant for both long- and short-term debt, which is not in line with the maturity-matching principle. Third, we replace asset growth by sales growth as proxy for growth opportunities. Our results are very similar to those reported in Sect. 4.1. Finally, to mitigate potential endogeneity issues, we ran regressions where we computed all explanatory variables using lagged values of total assets. Our results remain robust.

\section{Concluding remarks}

We employed a large, proprietary panel dataset to study the impact of firm and industry characteristics on the capital structure decisions of Dutch small firms. Our results on the impacts of firm characteristics are mostly in line with the predictions of the pecking-order theory. SMEs use profits to reduce their debt level, since they prefer internal funds over external funds. However, if a firm is growing, it increases its debt position because it needs more funds, and our results show that this happens according to the pecking-order theory. Furthermore, profits particularly affect short-term debt, whereas asset growth only affects long-term debt. Therefore, this suggests that, after internal funds, long-term debt comes next in the pecking order for SMEs. Shortterm debt is more expensive and can be amortized easily.

Our results also indicate that both inter- and intraindustry heterogeneity are important drivers of capital structure, in line with both pecking-order and trade-off theories of capital structure. Our analysis of inter-industry effects reveals that different industries exhibit different degrees of leverage, in line with the trade-off theory. The impact of firm characteristics for each industry is mostly in line with the peckingorder theory and this for almost all industries. Our intra-industry results indicate that firms display 
considerable heterogeneity after controlling for firm characteristics. This suggests that the degree of industry competition, the degree of agency conflicts, and the heterogeneity in employed technology are also important drivers of capital structure. A more detailed investigation of this is left for future research.

Acknowledgements We thank two anonymous referees, Martin Brown, Fabiana Penas, Bert Sikken, and Willem van der Velden, for comments that improved the paper.
Open Access This article is distributed under the terms of the Creative Commons Attribution Noncommercial License which permits any noncommercial use, distribution, and reproduction in any medium, provided the original author(s) and source are credited.

\section{Appendix}

See Table 6.

Table 6 Results from the industry-specific regressions

\begin{tabular}{|c|c|c|c|c|c|c|}
\hline & \multicolumn{2}{|c|}{ Total debt } & \multicolumn{2}{|c|}{ Long-term debt } & \multicolumn{2}{|c|}{ Short-term debt } \\
\hline & Estimate & Std. error & Estimate & Std. error & Estimate & Std. error \\
\hline \multicolumn{7}{|c|}{ Panel A: Manufacturing } \\
\hline Size $(\log )$ & $0.070^{*}$ & 0.0226 & $0.096^{*}$ & 0.0206 & -0.026 & 0.0185 \\
\hline Tangible assets & $0.390 *$ & 0.0508 & $0.519^{*}$ & 0.0458 & $-0.129 *$ & 0.0395 \\
\hline Intangible assets & 0.365 & 0.2019 & $0.418^{*}$ & 0.1855 & -0.115 & 0.1266 \\
\hline Net debtors & 0.333 & 0.0479 & 0.080 & 0.0417 & $0.252 *$ & 0.0386 \\
\hline ROA & $-0.186^{*}$ & 0.0418 & $-0.069 *$ & 0.0320 & $-0.117 *$ & 0.0308 \\
\hline Growth (assets) & $0.016^{*}$ & 0.0096 & 0.015 & 0.0093 & 0.001 & 0.0080 \\
\hline Tax rate & -0.003 & 0.0173 & -0.013 & 0.0148 & 0.011 & 0.0137 \\
\hline Depreciation & 0.112 & 0.1487 & -0.011 & 0.1347 & 0.123 & 0.1253 \\
\hline$R^{2}$ (firm fixed eff.) & 0.948 & & 0.960 & & 0.924 & \\
\hline$R^{2}$ (pooled) & 0.172 & & 0.402 & & 0.150 & \\
\hline FF test ( $p$-value) & 8.346 & $(0.000)$ & 7.786 & $(0.000)$ & 5.764 & $(0.000)$ \\
\hline \multicolumn{7}{|c|}{ Panel B: Construction } \\
\hline Size $(\log )$ & $0.080 *$ & 0.0243 & $0.092 *$ & 0.0217 & -0.012 & 0.0144 \\
\hline Tangible assets & $0.429 *$ & 0.0410 & $0.529 *$ & 0.0374 & $-0.100 *$ & 0.0304 \\
\hline Intangible assets & $0.449 *$ & 0.1724 & $0.557^{*}$ & 0.1666 & -0.108 & 0.0850 \\
\hline Net debtors & $0.275^{*}$ & 0.0333 & $0.055^{*}$ & 0.0254 & $0.220^{*}$ & 0.0273 \\
\hline ROA & $-0.138^{*}$ & 0.0277 & -0.023 & 0.0182 & $-0.115^{*}$ & 0.0205 \\
\hline Growth (assets) & $0.027 *$ & 0.0093 & $0.026^{*}$ & 0.0091 & 0.001 & 0.0065 \\
\hline Tax rate & -0.021 & 0.0157 & -0.016 & 0.0146 & -0.005 & 0.0140 \\
\hline Depreciation & $0.288^{*}$ & 0.1303 & 0.081 & 0.1094 & $0.208 *$ & 0.0986 \\
\hline$R^{2}$ (firm fixed eff.) & 0.946 & & 0.959 & & 0.915 & \\
\hline$R^{2}$ (pooled) & 0.231 & & 0.410 & & 0.104 & \\
\hline FF test ( $p$-value) & 6.474 & $(0.000)$ & 6.498 & $(0.000)$ & 4.639 & $(0.000)$ \\
\hline
\end{tabular}


Table 6 continued

\begin{tabular}{|c|c|c|c|c|c|c|}
\hline & \multicolumn{2}{|l|}{ Total debt } & \multicolumn{2}{|c|}{ Long-term debt } & \multicolumn{2}{|c|}{ Short-term debt } \\
\hline & Estimate & Std. error & Estimate & Std. error & Estimate & Std. error \\
\hline \multicolumn{7}{|c|}{ Panel C: Wholesale trade } \\
\hline Size $(\log )$ & $0.066^{*}$ & 0.0231 & $0.086^{*}$ & 0.0181 & -0.019 & 0.0161 \\
\hline Tangible assets & $0.344 *$ & 0.0579 & $0.494 *$ & 0.0487 & $-0.150 *$ & 0.0387 \\
\hline Intangible assets & $0.491 *$ & 0.1234 & $0.689 *$ & 0.1327 & -0.198 & 0.1242 \\
\hline Net debtors & $0.372 *$ & 0.0403 & $0.069^{*}$ & 0.0309 & $0.303 *$ & 0.0377 \\
\hline ROA & $-0.241 *$ & 0.0353 & $-0.092 *$ & 0.0281 & $-0.149 *$ & 0.0325 \\
\hline Growth (assets) & $0.019 *$ & 0.0088 & 0.011 & 0.0081 & 0.008 & 0.0076 \\
\hline Tax rate & 0.006 & 0.0162 & 0.010 & 0.0149 & -0.003 & 0.0144 \\
\hline Depreciation & 0.154 & 0.1517 & 0.066 & 0.1197 & 0.088 & 0.1313 \\
\hline$R^{2}$ (firm fixed eff.) & 0.950 & & 0.957 & & 0.929 & \\
\hline$R^{2}$ (pooled) & 0.141 & & 0.398 & & 0.141 & \\
\hline FF test ( $p$-value) & 8.857 & $(0.000)$ & 7.234 & $(0.000)$ & 6.108 & $(0.000)$ \\
\hline \multicolumn{7}{|c|}{ Panel D: Retail trade food } \\
\hline Size $(\log )$ & 0.062 & 0.0556 & $0.123^{*}$ & 0.0510 & $-0.061 *$ & 0.0290 \\
\hline Tangible assets & $0.445^{*}$ & 0.0813 & $0.494 *$ & 0.0914 & -0.049 & 0.0647 \\
\hline Intangible assets & 0.290 & 0.2517 & 0.433 & 0.2534 & -0.142 & 0.1153 \\
\hline Net debtors & $0.465^{*}$ & 0.1186 & 0.186 & 0.1043 & $0.279 *$ & 0.0900 \\
\hline ROA & -0.151 & 0.0791 & -0.042 & 0.0646 & $-0.109 *$ & 0.0551 \\
\hline Growth (assets) & 0.026 & 0.0224 & 0.012 & 0.0244 & 0.014 & 0.0164 \\
\hline Tax rate & 0.004 & 0.0377 & 0.015 & 0.0374 & -0.011 & 0.0316 \\
\hline Depreciation & 0.189 & 0.2495 & 0.069 & 0.2567 & 0.120 & 0.1686 \\
\hline$R^{2}$ (firm fixed eff.) & 0.953 & & 0.955 & & 0.908 & \\
\hline$R^{2}$ (pooled) & 0.261 & & 0.384 & & 0.093 & \\
\hline FF test ( $P$-value $)$ & 8.069 & $(0.000)$ & 6.933 & $(0.000)$ & 4.819 & $(0.000)$ \\
\hline \multicolumn{7}{|c|}{ Panel E: Retail trade nonfood } \\
\hline Size $(\log )$ & $0.074 *$ & 0.0188 & $0.083^{*}$ & 0.0177 & -0.009 & 0.0144 \\
\hline Tangible assets & $0.312 *$ & 0.0424 & $0.495^{*}$ & 0.0400 & $-0.182 *$ & 0.0306 \\
\hline Intangible assets & $0.321 *$ & 0.1496 & $0.521 *$ & 0.1570 & -0.200 & 0.1054 \\
\hline Net debtors & 0.430 & 0.0454 & $0.154 *$ & 0.0386 & $0.277 *$ & 0.0395 \\
\hline ROA & $-0.249 *$ & 0.0398 & $-0.095^{*}$ & 0.0297 & $-0.154 *$ & 0.0299 \\
\hline Growth (assets) & $0.027 *$ & 0.0072 & $0.028 *$ & 0.0073 & 0.000 & 0.0057 \\
\hline Tax rate & -0.016 & 0.0156 & -0.018 & 0.0152 & 0.001 & 0.0144 \\
\hline Depreciation & $0.396^{*}$ & 0.1364 & 0.188 & 0.1342 & 0.208 & 0.1142 \\
\hline$R^{2}$ (firm fixed eff.) & 0.955 & & 0.962 & & 0.930 & \\
\hline$R^{2}$ (pooled) & 0.140 & & 0.359 & & 0.148 & \\
\hline FF test ( $p$-value) & 10.570 & $(0.000)$ & 9.267 & $(0.000)$ & 6.579 & $(0.000)$ \\
\hline
\end{tabular}


Table 6 continued

\begin{tabular}{|c|c|c|c|c|c|c|}
\hline & \multicolumn{2}{|l|}{ Total debt } & \multicolumn{2}{|c|}{ Long-term debt } & \multicolumn{2}{|c|}{ Short-term debt } \\
\hline & Estimate & Std. error & Estimate & Std. error & Estimate & Std. error \\
\hline \multicolumn{7}{|c|}{ Panel F: Catering and leisure } \\
\hline Size $(\log )$ & $0.118^{*}$ & 0.0283 & $0.164 *$ & 0.0266 & $-0.046^{*}$ & 0.0163 \\
\hline Tangible assets & $0.339 *$ & 0.0537 & $0.350^{*}$ & 0.0513 & -0.011 & 0.0343 \\
\hline Intangible assets & $0.353^{*}$ & 0.1716 & $0.426^{*}$ & 0.1502 & -0.073 & 0.1012 \\
\hline Net debtors & $0.344 *$ & 0.1001 & $0.252^{*}$ & 0.0975 & 0.092 & 0.0771 \\
\hline ROA & $-0.128 *$ & 0.0493 & $-0.067 *$ & 0.0339 & -0.061 & 0.0390 \\
\hline Growth (assets) & 0.014 & 0.0085 & $0.016^{*}$ & 0.0079 & -0.002 & 0.0048 \\
\hline Tax rate & -0.029 & 0.0261 & -0.028 & 0.0238 & -0.001 & 0.0186 \\
\hline Depreciation & $0.317 *$ & 0.1104 & $0.232 *$ & 0.0870 & 0.085 & 0.0942 \\
\hline$R^{2}$ (firm fixed eff.) & 0.963 & & 0.968 & & 0.932 & \\
\hline$R^{2}$ (pooled) & 0.228 & & 0.335 & & 0.117 & \\
\hline FF test ( $p$-value) & 9.731 & $(0.000)$ & 9.869 & $(0.000)$ & 5.927 & $(0.000)$ \\
\hline \multicolumn{7}{|l|}{ Panel G: Transport } \\
\hline Size $(\log )$ & $0.092 *$ & 0.0213 & $0.114^{*}$ & 0.0228 & -0.023 & 0.0175 \\
\hline Tangible assets & $0.393 *$ & 0.0666 & $0.511^{*}$ & 0.0707 & $-0.118^{*}$ & 0.0444 \\
\hline Intangible assets & 0.252 & 0.3891 & 0.108 & 0.3385 & 0.143 & 0.2491 \\
\hline Net debtors & $0.383^{*}$ & 0.0714 & 0.151 & 0.0838 & $0.233^{*}$ & 0.0514 \\
\hline ROA & $-0.248 *$ & 0.0638 & $-0.105^{*}$ & 0.0531 & $-0.143^{*}$ & 0.0433 \\
\hline Growth (assets) & $0.024 *$ & 0.0083 & 0.017 & 0.0097 & 0.007 & 0.0080 \\
\hline Tax rate & -0.037 & 0.0253 & -0.040 & 0.0251 & 0.003 & 0.0213 \\
\hline Depreciation & $0.310^{*}$ & 0.1374 & 0.111 & 0.1634 & 0.198 & 0.1136 \\
\hline$R^{2}$ (firm fixed eff.) & 0.959 & & 0.958 & & 0.916 & \\
\hline$R^{2}$ (pooled) & 0.264 & & 0.419 & & 0.191 & \\
\hline FF test ( $p$-value) & 10.568 & $(0.000)$ & 8.083 & $(0.000)$ & 5.378 & $(0.000)$ \\
\hline \multicolumn{7}{|l|}{ Panel H: Services } \\
\hline Size $(\log )$ & $0.057 *$ & 0.0193 & $0.069 *$ & 0.0171 & -0.011 & 0.0143 \\
\hline Tangible assets & $0.390 *$ & 0.0444 & $0.471^{*}$ & 0.0424 & $-0.081^{*}$ & 0.0281 \\
\hline Intangible assets & $0.279 *$ & 0.1170 & $0.355^{*}$ & 0.1026 & -0.076 & 0.0675 \\
\hline Net debtors & $0.258 *$ & 0.0442 & 0.046 & 0.0331 & $0.212^{*}$ & 0.0360 \\
\hline ROA & $-0.098 *$ & 0.0352 & -0.042 & 0.0243 & $-0.056^{*}$ & 0.0273 \\
\hline Growth (assets) & $0.022 *$ & 0.0075 & $0.015^{*}$ & 0.0069 & 0.007 & 0.0056 \\
\hline Tax rate & -0.026 & 0.0149 & -0.025 & 0.0140 & -0.001 & 0.0123 \\
\hline Depreciation & 0.104 & 0.1111 & -0.090 & 0.0937 & $0.193^{*}$ & 0.0848 \\
\hline$R^{2}$ (firm fixed eff.) & 0.954 & & 0.967 & & 0.945 & \\
\hline$R^{2}$ (pooled) & 0.176 & & 0.402 & & 0.192 & \\
\hline FF test ( $p$-value) & 7.134 & $(0.000)$ & 7.194 & $(0.000)$ & 5.801 & $(0.000)$ \\
\hline
\end{tabular}

Notes: * Significant at the $5 \%$ level

\section{References}

Ang, J. S. (1992). On the theory of finance for privately held firms. Journal of Small Business Finance, 1(3), 185-203.

Baker, M., \& Wurgler, J. (2002). Market timing and capital structure. Journal of Finance, 57(1), 1-32.
Balakrishnan, S., \& Fox, I. (1993). Asset specificity, firm heterogeneity and capital structure. Strategic Management Journal, 14(1), 3-16.

Berger, A. N., \& Udell, G. F. (2006). A more conceptual framework for SME finance. Journal of Banking and Finance, 30(11), 2945-2966. 
Bradley, M., Jarrell, G., \& Kim, E. (1984). On the existence of an optimal capital structure: Theory and evidence. Journal of Finance, 39(3), 857-878.

Brennan, M. J., \& Schwartz, E. S. (1978). Corporate income taxes, valuation and the problem of optimal capital structure. Journal of Business, 51, 103-114.

Cassar, G., \& Holmes, S. (2003). Capital structure and financing of SMEs: Australian evidence. Accounting and Finance, 43(2), 123-147.

Cetorelli, N., \& Gambera, M. (2001). Banking market structure, financial dependence and growth: International evidence from industry. Journal of Finance, 56(2), 617-648.

Chen, L. H., Lensink, R., \& Sterken, E. (1999). The determinants of capital structure: Evidence from Dutch panel data, working paper University of Groningen.

Cole, R. (2008). What do we know about the capital structure of privately held firms? Evidence from the Surveys of Small Business Finance. http://www.sba.gov/advo/ research/rs324tot.pdf.

De Jong, A. (1999). An empirical analysis of capital structure decisions in Dutch firms. PhD. dissertation. CentER, Tilburg University.

De Jong, A., Kabir, R., \& Nguyen, T. T. (2008). Capital structure around the world: The roles of firm- and countryspecific determinants. Journal of Banking and Finance, 32, 1954-1969.

DeAngelo, H., \& Masulis, R. W. (1980). Optimal capital structure under corporate and personal taxation. Journal of Financial Economics, 8, 3-29.

Fama, E. F. (1980). Agency problems and the theory of the firm. Journal of Political Economy, 88, 288-307.

Fama, E. F., \& French, K. R. (2002). Testing trade-off and pecking order predictions about dividends and debt. Review of Financial Studies, 15(1), 1-33.

Frank, M., \& Goyal, V. K. (2008). Trade-off and pecking order theories of debt. In E. Eckbo (Ed.), The handbook of empirical corporate finance. North Holland: Elsevier.

Graham, J. R., \& Harvey, C. R. (2001). The theory and practice of corporate finance: Evidence from the field. Journal of Financial Economics, 60, 187-243.

Hall, G. C., Hutchinson, P. J., \& Nicos, M. (2004). Determinants of the capital Structures of European SMEs. Journal of Business Finance and Accounting, 31(5\&6), 711-728.

Harris, M., \& Raviv, A. (1991). The theory of capital structure. Journal of Finance, 46(1), 297-355.

Heyman, D., Deloof, M., \& Ooghe, H. (2008). The financial structure of privately held Belgian firms. Small Business Economics, 30, 301-313.

Jensen, M. C. (1986). Agency costs of free cash flow, corporate finance and takeovers. The American Economic Review, Papers and Proceedings, 76, 323-329.

Jordan, J., Lowe, J., \& Taylor, P. (1998). Strategy and financial policy in UK small firms. Journal of Business Finance and Accounting, 25(1\&2), 1-27.
Leibenstein, H. (1966). Allocative Efficiency vs. 'X-Efficiency'. The American Economic Review, 56, 392-415.

MacKay, P., \& Phillips, G. (2005). How does industry affect firm financial structure? The Review of Financial Studies, 18(4), 1433-1466.

Maksimovic, V., \& Zechner, J. (1991). Debt, agency costs and industry equilibrium. Journal of Finance, 54, 1619-1645.

Michaelas, N., Chittenden, F., \& Poutziouris, P. (1999). Financial policy and capital structure choice in U.K. SMEs: Empirical evidence from company panel data. Small Business Economics, 12(2), 113-130.

Mitchel, K. (1991). The call, sinking fund and term-to-maturity features of corporate bonds: An empirical investigation. Journal of Financial and Quantitative Analysis, 26, 201222.

Modigliani, F., \& Miller, M. H. (1958). The cost of capital, corporation finance and the theory of investment. The American Economic Review, 48(3), 261-297.

Modigliani, F., \& Miller, M. H. (1963). Corporate income taxes and the cost of capital: A correction. The American Economic Review, 53(3), 433-443.

Myers, S. C. (1977). Determinants of corporate borrowing. Journal of Financial Economics, 5, 147-175.

Myers, S. C. (1984). The capital structure puzzle. Journal of Finance, 39, 575-592.

Myers, S. C., \& Majluf, N. S. (1984). Corporate financing and investment decisions when firms have information that investors do not have. Journal of Financial Economics, $13,187-221$.

Ortiz-Molina, H., \& Penas, M. (2006). Lending to small business: The role of loan maturity in addressing information problems. Small Business Economics, 30, 361383.

Sogorb-Mira, F. (2005). How SME uniqueness affects capital structure: Evidence from a 1994-1998 Spanish data panel. Small Business Economics, 25(5), 447-457.

Stulz, R. (1988). Managerial control of voting rights: Financing policies and the market for corporate control. Journal of Financial Economics, 20, 25-54.

Titman, S., \& Wessels, R. (1988). The determinants of capital structure choice. Journal of Finance, 43(1), 1-19.

Van der Wijst, N., \& Thurik, R. (1993). Determinants of small firm debt ratios-an analysis of retail panel data. Small Business Economics, 5(1), 55-65.

Van Dijk, R. (1997). Corporate finance and equity investment: Panel data analyses. $\mathrm{PhD}$. dissertation. Tinbergen Institute Research Series no. 168, Erasmus University Rotterdam.

Verbeek, M. (2008). A guide to modern econometrics (3rd ed.). Chichester: Wiley.

Vos, E., Yeh, A., Carter, S., \& Tagg, S. (2007). The happy story of small business financing. Journal of Banking and Finance, 31, 2648-2672. 